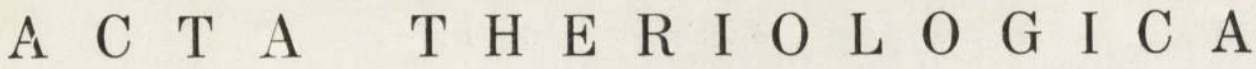

VOL. XVII, 3: $33-40$.

BIAŁOWIEŹA

May, 1972

\author{
Gabriela B U J A L S K A \& Joanna G L I W I C Z
}

\section{Growth and Reproduction of Female Bank Voles Under Field Conditions}

\author{
[With 1 Table \& 2 Figs]
}

\begin{abstract}
The growth of body weight of sexually mature, immature and adolescent females was investigated. The general character of the growth curve of sexually mature and immature females is similar, although mature females are always heavier than immature females of the same age. After winter the changes in body weight of mature females are not connected with growth. Overwintered individuals are characterized by more uniform body weights than females in autumn what shows that differences in body weight between mature and immature females disappear during the autumn-winter season. Increase in body weight of females during pregnancy and after pregnancy was analysed. The highest increase in body weight was found in females breeding for the first time. The dependence of rate of increase in body weight on social relations is discussed, and an attempt made at interpreting the causes of differences in growth rate between spring and autumn generations.
\end{abstract}

\section{INTRODUCTION}

The growth of body weight of Clethrionomys glareolus was investigated under both laboratory (S viridenk o, 1959; M a z ák, 1962; D r o ż d ż, 1965) and natural conditions (K ošk in a, 1955; Il ye nko \& Z u bčaninova, 1963; B ergstedt, 1965; Bujalska \& Gliw ic z, 1968; Z e jda, 1971 and others). It was not always possible to describe the growth curve of females on account of their participation in reproduction (pregnancy) and in such cases the majority of authors consider the growth curve of males only (e.g. D rożd ż, 1965; B u j a lska \& Gliwicz, 1968).

In this paper relations between the growth of body weight and the reproductive condition of females have been investigated. For this purpose examination was made of the growth of body weight of sexually immature and mature females and also of increase in weight during pregnancy. 


\section{STUDY AREA AND METHODS}

Material included in this paper forms the result of three years' investigations (1966-1968) carried out on a population of C. glareolus inhabiting Crab Apple Island on Bełdany Lake (north-east Poland).

The island, four hectars in area, is covered with mixed forest which is the natural habitat of the bank vole. Five two-week censuses were carried out by means of the $C M R$ methods from mid-April to the end of October in each year. Live traps with bait (oats) were distributed evenly over the whole island. During each census all individuals of the population were caught (Andrzejewski, Petrusewicz \& Waszkiewicz-Gliwicz, 1967).

Each time an individual was caught its number and weight were recorded and a vaginal smear taken from mature females. In this way, series of data were obtained for each individual on its body weight and reproductive condition. A total of 613 females were caught and 11,079 captures made.

Each year the population consisted of overwintered animals and the individuals born in the current year, among which age groups (cohorts) could be distinguished, according to the time of their appearance in the population. Analysis of vaginal smears made it possible to distinguish sexually immature and mature females, and in the last group pregnant and non-pregnant ones (B ujals ka, Andrzejewski \& Petrusewicz, 1968; Bujalska, 1970). During each breeding season females were observed to transfer from the immature to the mature group, and within the latter group from pregnant to non-pregnant and vice versa.

\section{RESULTS}

\subsection{Growth Rate of Sexually Immature and Mature Females}

To characterize the growth of immature and mature females the data obtained from all cohorts in the first census and during subsequent censuses were averaged (Fig. 1, Table 1). The category of adolescent females was distinguished, but the curve in Fig. 1 does not characterize their real growth; it represents the weight of the adolescent females in consecutive censuses. The growth curve of adolescent females is thus only of comparative value.

In the group of mature females (not pregnant at the time) two categories were distinguished: the young of the current year and overwintered females. The group of mature individuals of the current year consisted of females which had recently reached sexual maturity and had never yet been pregnant, and females which, having reached puberty earlier, had bred once or more times.

The general character of growth of mature females of the current year is similar to that of immature females (Fig. 1).

The higher weight of mature individuals at all times is remarkable, and confirms the results obtained by Bergsted $\mathrm{t}$ (1965) and $\mathrm{Zejda}$ (1971). The differences between all points on both curves are statistically 
significant $(0.01>P>0.001)$, and this situation lasts until the end of the breeding season, when females belonging to both categories reach the age of about five months.

The group of overwintered individuals consists entirely of females (older than the above-mentioned ones) which had had the opportunity of breeding many times during both the previous and the current year. In

Table 1

Average body weight growth of different groups of females.

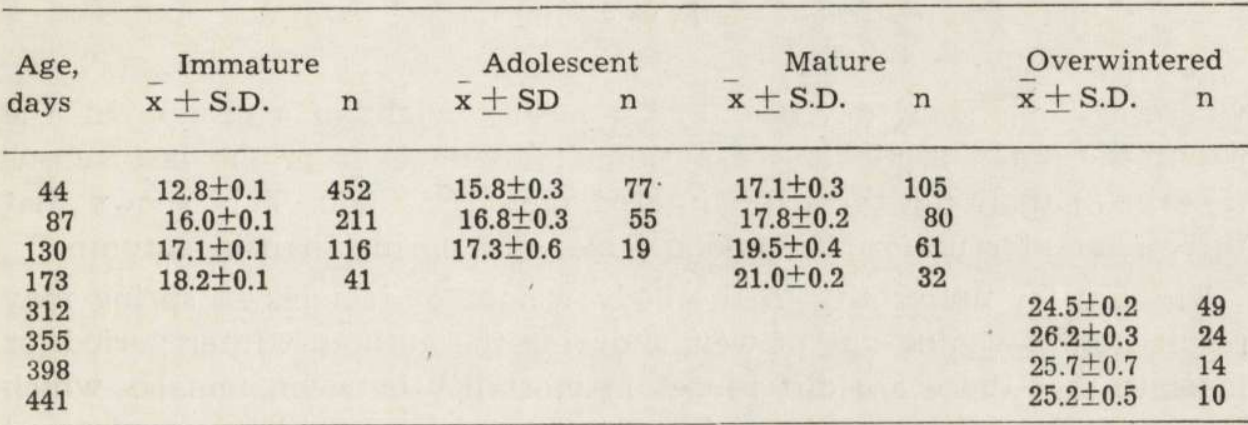

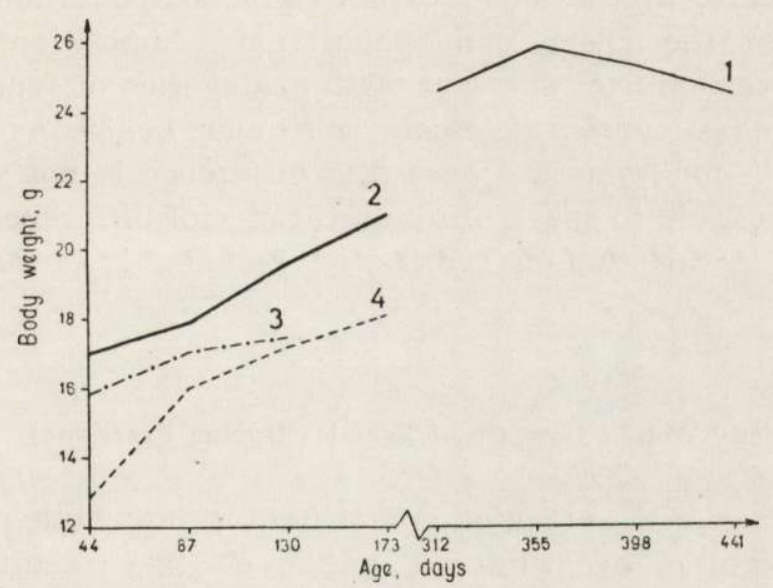

Fig. 1. Comparison of the individual growth curves of different groups of females.

1 - Overwintered, 2 - Mature, 3 - Adolescent, 4 - Immature.

this group the weight of females is very similar in all the study years and changes are not of a growth character (Fig. 1), which is in accordance with the observations of $\mathrm{K}$ os k in a (1955). Comparison of the curve of body weight changes of these females with the curves of other groups proves that overwintered individuals form a separate group in respect of weight. The differences between the growth curve of mature and adoles- 
cent females show that the higher weight of mature females may be connected with their previous pregnancies.

Since the group of overwintered individuals includes females belonging to two significantly different weight groups at the end of previous breeding season, their body weight in autumn was compared with that in spring of the next year, during the first census. The comparison was made with the use of variability index:

$$
I_{v}=\frac{\delta}{\bar{x}} 100
$$

where $\delta$ - standard deviation, $\bar{x}-$ mean weight of a group. In the result the index is higher for autumn individuals from the last census $\left(I_{v}=10.8\right)$ than for the overwintered ones $\left(I_{v}=8.6\right)$. This shows that there is greater uniformity among females in spring than in autumn.

The greater uniformity in the body weight of females in spring may result from sevening-up " of weight during the autumn-winter period, or indicate that there are differences in mortality between females which had reached sexual maturity before winter and those which overwintered while still immature. In the latter case weight compensation in spring would result from the changes in population composition caused by greater or lesser capacity for survival of the categories of females. Since the survival of both categories of females is similar, i.e. $30.3 \%$ for mature females and $33.9 \%$ for immature ones (the difference is not statistically significant) it is possible to speak of disappearance of differences between the body weight of the two categories of females in autumn-winter period.

\subsection{Body Weight Inerease of Females During Pregnancy}

The analysis was aimed, among others, at finding out whether the difference in body weight of overwintered individuals may result from the higher number of their pregnancies.

Only those cases were considered in which the first day of pregnancy ( 54 cases) or the day of birth of the young ( 73 cases) could be determined and the character of the body weight of the female before pregnancy or after parturition was known. In both cases the analysis was based, if possible, on series of measurements of body weight.

If the copulation (presence of vaginal plug) or the parturition (observation of parturition in the trap or symptoms of lactation determined on the basis of plucked fur around the teats) were not directly observed, 
the days on which they may have taken place were interpolated ${ }^{1}$ ). In the first case half of the interval between the last observation proving the absence of pregnancy (presence of oestrus cycle) and the first observation of pregnancy was accepted; in the second case half of the interval between the last observation of pregnancy and the first observation proving lack of pregnancy (the presence of oestrus, observation of lactation etc.) was accepted.

Lack of precise information of length of gestation which, according to different authors, may fluctuate under natural condions from 17 to 25 days (Wr a ng e 1, 1940; P o p ov, 1960; Drożd ż, 1963; B u ja ls k a \& Ryszkowski, 1966) and difficulties in determining its length under

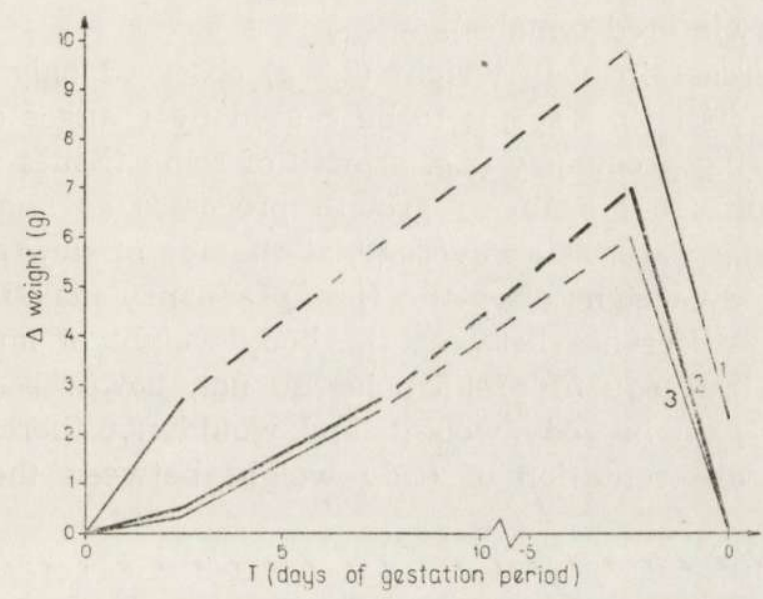

Fig. 2. Changes of body weight during pregnancy.

1 - First pregnancy, 2 - Next pregnancies, 3 - Pregnancies of overwintered.

field conditions with short series of captures (duration of one census was shorter than the length of gestation) made it impossible to determine weight increase during the whole pregnancy.

Weight increase was compared for three points: mean gain of body weight recorded in the period between the first and the fifth day of pregnancy (on average 2.5 days), between the fifth and the tenth day (on average 7.5 days) and between the fifth day before parturition and the last day of pregnancy (on average 2.5 days of the final period of pregnancy). For the current year's females in the course of their first pregnancy it was possible to delineate weight gains on the grounds

1) Only females for which the interval between captures was not longer than 2.5 days were taken for this analysis giving interpolation with accuracy to about 1 day. 
of first two points only. The highest gain in body weight was recorded for young females pregnant for the first time (Fig. 2). After parturition these females are $2.3 \mathrm{~g}$ heavier than before pregnancy (their mean weights were $17.4 \pm 0.4$ and $19.7 \pm 0.5$ ). By means of $t$ Student test the gain in body weight was found to be statistically significant $(0.01>P$ $>0.001$ ). Relative gain in body weight during subsequent pregnancies of the current year's and overwintered females is virtually similar i.e. during the period of the last five days of pregnancy their weight is respectively 7 and 6 grams $(30 \%$ and $24 \%)$ higher than the initial weight. However, their weight after parturition does not display statistically significant changes in relation to weight before pregnancy (respectively $21 \pm 0.6$ and $20.6 \pm 0.5$ for current year and $25.4 \pm 0.7$ and $24.7 \pm 04$ for overwintered females).

Significant increase in body weight $(2.3 \mathrm{~g})$ observed only for females breeding for the first time seems to be caused by changes occurring in the organism during pregnancy (e.g. growth of some tissues and organs). It does not result from ordinary growth processes as females during their first pregnancy are, as an average, at the age of slow growth rate.

The gain in body weight after the first pregnancy may influence, to some extent, the difference between the body weight of immature and mature females. Subsequent pregnancies do not, however seem to result in constant gain in body weight, and would not therefore appear to take part in differentation of body weight between the two catcgories of females.

\section{DISCUSSION}

The material covered by this paper shows that:

1. Mature females are heavier than immature ones of the same age.

2. Attainment of sexual maturity is correlated with relatively higher body weight.

3. After the first parturition a significant gain in body weight can be observed (in relation to weight before pregnancy), due to the processes connected with pregnancy.

Differences in growth of body weight of immature and mature females may result from population phenomena. A ndrzejew ski et al. (1967) found a dependence between the body weight of individuals, the size of their home ranges and their trappability. The authors presented a hypothesis maintaining that individuals belonging to a higher social rank display, among others, higher body weight.

Applying similar reasoning to interpret the results of this study it may be assumed that mature females are privileged individuals in the 
population, hence they gain and maintain much higher body weight during their first breeding season than immature females. This privileged position can be also proved by a more uniform distribution of individual home ranges, their slighter mutual overlapping and better trappability of mature females when compared with immature ones $(\mathrm{Bujalska}$, 1970).

The results obtained also contribute to a broader interpretation of the difference between the spring and autumn generations in small rodent populations. Ad a mczewska (1961), Schwartz et al. (1964), B erg stedt (1965), A d a m czewska-Andrzejewska (1971) emphasise faster growth and gaining of higher body weight by individuals of the spring generation. On the other hand, it is known that it is mainly these individuals which take part in reproduction in the year of their birth. Thus the growth of body weight of the spring generation may results from the higher share of sexually mature individuals than in the autumn generation.

If this factor is in fact important then, with experimental or natural transfer of "reproduction duties " from the spring to the autumn generation, the latter should be characterized by more intensive growth of body weight.

\section{REFERENCES}

1. Adamczewska K., 1961: Intensity of reproduction of the Apodemus flavicollis (M e l chior, 1834) during period 1954-1959. Acta theriol., 5: 1-21.

2. A damczewska-Andrzejewska K., 1971: Methods of age determination in Apodemus agrarius (P a $11 \mathrm{a} \mathrm{s,} \mathrm{1771).} \mathrm{Ann.} \mathrm{zool.} \mathrm{Fenn.,} \mathrm{8:} \mathrm{68-71.}$

3. Andrzejewski R., Petrusewicz K. \& Waszkiewicz-Gliwicz J., 1967: The trappability of Clethrionomys glareolus and other ecological parameters obtained by $C M R$ capture method. Ekol. pol. A, 15: 709-725.

4. Bergstedt B., 1965: Distribution, reproduction, growth and dynamics of rodent species Clethrionomys glareolus ( $\mathrm{Schreber}$ ), Apodemus flavicollis (Melchior) and Apodemus sylvaticus (Linné) in southern Sweden. Oikos, 16: $132-160$.

5. Buja lska G., 1970: Reproduction stabilizing elements in an island populatior. of Clethrionomys glareolus (S chreber, 1780). Acta theriol., 15: 381-412.

6. Bujalska G., Andrzejewski R. \& Petrusewicz K., 1968: Productivity investigation of an island population of Clethrionomys glareolus (S c hreber, 1780). II. Natality. Acta theriol., 13: 415-425.

7. Bujalska G. \& Gliwicz J., 1968: Productivity investigation of an island population of Clethrionomys glareolus (S chreber, 1780), III. Individual growth curve. Acta theriol. 13: 427-433.

8. Bujalska G. \& Ryszkowski L., 1966: Estimation of the reproduction of the bank vole under field conditions. Acta theriol., 11: $351-361$.

9. Drożḋ̇ A., 1965: Wplyw paszy na dojrzewanie samców nornicy rudej (Clethrionomys glareolus, Schr.). Zwierz. lab., 3: 34-45. 
10. Ilyenko A. J. \& Zubčaninova E. V., 1963: Kruglogodiěnyje nabludenia za mečenymi ryžimi polevkami i lesnymi myšami v Podmoskove. Zool. Žurn., 42: $609-617$.

11. Koškina T. V., 1965: Metod opredelenia vozrosta ryžih polevok i opyt ego primienienia. Zool. Žurn., 34: 631-639.

12. Mazák V., 1962: Zur Kenntnis der postnatalen Entwicklung der Rötelmaus, Clethrionomys glareolus, Schreber, 1780 (Mammalia, Microtidae). Věst. Csl. Spol. Zool., 26: 77-104.

13. P o p o v V., 1960: Mlekopitajuščie Volžsko-Kamskogo kraja. Akad. Nauk SSSR; 1-468. Kazan.

14. Schwarz S. S., Pokrovski A. V., Istchenko V. G., Olenjev V. G., Ovtschinnikova N. A. \& Pjastolova O. A., 1963: Biological peculiarities of seasonal generations of rodents with special reference to the problem of senescence in mammals. Acta theriol., 8: 11-43.

15. S viride nko P. A., 1959: Rost i rozvite evropeiskoi ryžei polevki (Clethrionomys glareolus Schreb.). Zool. Žurn., 38: 756-766.

16. Wrangel H. F., 1940: Beiträge zur Biologie der Rötelmaus Clethrionomys glareolus Schr. Z. Säugetierkde, 14: 52-93.

17. Zejda J., 1971: Differential growth of three cohorts of the bank vole, Clethrionomys glareolus Schreb. 1780. Zool. Listy, 20: 229-245.

Accepted, December 24, 1971.

Institute of Ecology,

Polish Academy of Sciences,

Dziekanów Leśny n/Warszawa, Poland

\section{Gabriela BUJALSKA i Joanna GLIWICZ}

WZROST CIĘŻARU CIAŁA A UDZIA£ W ROZRODZIE SAMIC NORNICY RUDEJ

\section{W WARUNKACH TERENOWYCH}

\section{Streszczenie}

Prześledzono tempo wzrostu ciężaru ciała samic niedojrzalych i dojrzalych płciowo oraz samic aktualnie dojrzewających (Tab. 1, Ryc. 1). Wyniki obserwacji wskazują, że jakkolwiek ogólny charakter wzrostu samic dojrzałych i niedojrzałych płciowo jest podobny, to samice dojrzałe są zawsze cięższe od będących w tym samym wieku samic niedojrzałych. Po przezimowaniu zmiany ciężaru ciała samic nie mają charakteru wzrostowego. Stwierdzono również, że na wiosnę samice charakteryzują się większą jednorođnością ciężaru ciała niż samice na jesieni, co jest rezultatem zanikania w okresie jesienno-zimowym różnic w ciężarze ciała między samicami dojrzałymi i niedojrzałymi.

W dalszym ciągu prześledzono wzrost ciężaru ciała samic podczas ciąży oraz przyrost ciężaru ciała po przebytej ciąży (Ryc. 2). Największy przyrost ciężaru ciała zaobserwowano u samic rodzących po raz pierwszy.

Przedyskutowano zależność tempa wzrostu ciężaru ciała od stosunków socjalnych $\mathrm{w}$ populacji oraz podjęto próbę interpretacji przyczyn różnego tempa wzrostu generacji wiosennych i jesiennych. 